\title{
EGFR/erb-1, HER2/erb-2, CK7, LP34, Ki67 and p53 expression in preneoplastic lesions of bronchial epithelium
}

\author{
Lina Carvalho ${ }^{1,2,3,4^{*}}$, Joana E Santo ${ }^{1}$, Ana Alarcão ${ }^{1,2}$, Patricia Couceiro ${ }^{1,2}$, Maria R Silva ${ }^{1,2,3}$, Ana Gomes ${ }^{2,4}$, \\ Maria J d'Aguiar', Lia Teixeira', Vitor Sousa ${ }^{1,2,3,4}$ \\ From 16th International Charles Heidelberger Symposium on Cancer Research \\ Coimbra, Portugal. 26-28 September 2010
}

A prognostic interpretation of preneoplastic lesions would have impact in bronchial carcinoma early diagnosis and through the study of Erb-B family receptors as they have an important role in lung carcinogenesis. The existence of drugs as tirosine kinase inhibitors (TKis) stressed the importance of studying gene alterations for selected chemoprevention schemes and characterization of carcinogenesis.

Bronchial preneoplastic lesions were characterized by immunohistochemistry using the antibodies LP34 (high weigh molecular cytokeratin), CK7, Chromogranin A, Ki67, p53, C-erbB-2 and EGFR. HER2 and EGFR gene copy number was also evaluated by fluorescent in situ hybridization (FISH) in those lesions.

The expected results defined the origin cell for basal cell hyperplasia and squamous metaplasia as adaptative lesions and dysplasia. By known experiences and published data, beyond the stem cell, the spectral evolution of bronchial preneoplastic lesions was demonstrated by characterizing basal cells (LP34) and their neoplastic potentiality.

Dysplasias showed a higher expression of EGFR, Ki67 and p53 with a stepwise increase with the gravity of the respective grading. C-erbB-2 immunohistochemical overexpression was a rare event in preneoplastic lesions. Polysomy was the main mechanism for EGFR and $H E R 2 / n e u$ higher gene copy number and together with increased proliferation index (Ki67) will account to preview bronchial carcinogenesis.

\footnotetext{
* Correspondence: Icarvalho@huc.min-saude.pt

'Instituto de Anatomia Patológica - Faculdade de Medicina da Universidade de Coimbra, Coimbra, Portugal

Full list of author information is available at the end of the article
}

\section{Author details}

'Instituto de Anatomia Patológica - Faculdade de Medicina da Universidade de Coimbra, Coimbra, Portugal. ${ }^{2}$ Centro de Investigação em Meio Ambiente, Genética e Oncobiologia (CIMAGO), Coimbra, Portugal. ${ }^{3}$ Centro de Pneumologia - Faculdade de Medicina da Universidade de Coimbra, Coimbra, Portugal. ${ }^{4}$ Serviço de Anatomia Patológica dos Hospitais da Universidade de Coimbra, Coimbra, Portugal.

Published: 24 September 2010

\section{doi:}

Cite this article as: Carvalho et al: EGFR/erb-1, HER2/erb-2, CK7, LP34, $\mathrm{Ki} 67$ and $\mathrm{p} 53$ expression in preneoplastic lesions of bronchial epithelium. BMC Proceedings 2010 4(Suppl 2):P64.
Submit your next manuscript to BioMed Central and take full advantage of:

- Convenient online submission

- Thorough peer review

- No space constraints or color figure charges

- Immediate publication on acceptance

- Inclusion in PubMed, CAS, Scopus and Google Scholar

- Research which is freely available for redistribution

Submit your manuscript at www.biomedcentral.com/submit
Biomed Central 